\title{
PM070747, a new cytotoxic angucyclinone from the marine-derived Saccharopolyspora taberi PEM-06-F23-019B
}

\author{
Marta Pérez ${ }^{1}$, Carmen Schleissner ${ }^{1}$, Pilar Rodríguez ${ }^{1}$, Paz Zúñiga ${ }^{1}$, Gonzalo Benedit ${ }^{1}$, Francisco Sánchez- \\ Sancho $^{2}$ and Fernando de la Calle ${ }^{1}$
}

The Journal of Antibiotics (2009) 62, 167-169; doi:10.1038/ja.2008.27; published online 23 January 2009

Keywords: angucyclinone; isolation; PM070747; Saccharopolyspora taberi; structural elucidation

The benz $[\alpha]$ anthraquinones are a class of compounds that have attracted a great deal of attention owing to their interesting biological properties.

As part of our on-going screening for new antitumor compounds from marine microorganisms, we have isolated a new angucyclinone, PM070747 (1) (Figure 1), produced by the actinomycete Saccharopolyspora taberi PEM-06-F23-019B, from a marine sponge collected from near the coast of Tanzania. Additionally, traces of the known angucyclinone, $\mathrm{PD} 116740^{1}$ (2), were also found.

Compound 1 is structurally closely related to 2 and TAN- $1085^{2}(3)$ (Figure 1). Compound 2 was first isolated from the unknown actinomycete, WP4669, and it was described as a compound with antitumor properties against leukemia and adenocarcinoma cell lines. ${ }^{1}$ Recently, an epimer of 2 was isolated from a marine fungus, Penicillium sp. ${ }^{3}$ Compound 3 and its aglycone were described as angiogenesis and aromatase inhibitors in the Japanese patent JP02289532. ${ }^{2}$

The microbial producer of 1, Saccharopolyspora taberi PEM-06-F23019B, was isolated by spreading the homogenized ectosome of the sponge on Bennett's agar medium ${ }^{4}$ plates supplemented with nalidixic acid $(0.02 \%)$ and cycloheximide $(0.02 \%)$. The plates were incubated at $28^{\circ} \mathrm{C}$ for 30 days.

The strain was subjected to a phylogenetic analysis based on $16 \mathrm{~S}$ rRNA sequences analyzed by BLAST (Basic Local Alignment Search Tool) against the NCBI (National Center for Biotechnology Information) database, ${ }^{5}$ and showed a high identity with that of Saccharopolyspora, such as Saccharopolyspora taberi DSM 43856 (956/968, 98.8\%) (sequence AF002819). ${ }^{6}$

The seed culture was developed in two scale-up steps, first in 100-ml Erlenmeyer flasks containing $20 \mathrm{ml}$ of seed medium, and then in 250-ml Erlenmeyer flasks with $50 \mathrm{ml}$ of the same medium. The seed culture was grown on a medium containing dextrose $(0.1 \%)$, soluble starch $2.4 \%$, soy peptone $0.3 \%$, yeast extract $0.5 \%$, Tryptone $0.5 \%$, soya flour $0.5 \%$, $\mathrm{NaCl} 0.54 \%, \mathrm{KCl} 0.02 \%, \mathrm{MgCl}_{2} 0.24 \%, \mathrm{Na}_{2} \mathrm{SO}_{4} 0.75 \%$ and $\mathrm{CaCO}_{3}$ $0.4 \%$ in tap water, and cultured at $28^{\circ} \mathrm{C}$ on an orbital shaker for $72 \mathrm{~h}$. For production, $12.5 \mathrm{ml}$ of the seed medium was transferred into 2000$\mathrm{ml}$ Erlenmeyer flasks containing $250 \mathrm{ml}$ of fermentation medium, comprising yeast extract $0.5 \%$, soy peptone $0.1 \%$, dextrose $0.5 \%$, soya flour $0.3 \%$, Glucidex $2.0 \%, \mathrm{NaCl} 0.53 \%, \mathrm{KCl} 0.02 \%, \mathrm{MgCl}_{2} \cdot 6 \mathrm{H}_{2} \mathrm{O}$ $0.24 \%, \mathrm{Na}_{2} \mathrm{SO}_{4} 0.75 \%, \mathrm{MnSO}_{4} \cdot 4 \mathrm{H}_{2} \mathrm{O} 0.00076 \%, \mathrm{CoCl}_{2} \cdot 6 \mathrm{H}_{2} \mathrm{O} 0.0001 \%$, $\mathrm{K}_{2} \mathrm{HPO}_{4} 0.05 \%$ and $\mathrm{CaCO}_{3} 0.4 \%$. The culture was grown at $28^{\circ} \mathrm{C}$ using an orbital shaker (5-cm eccentricity, 220 r.p.m.) for 5 days.

The bioassay-guided isolation of $\mathbf{1}$ from the fermentation broth is depicted in Figure 2 and summarized below.

The fermentation broth (6l) was subjected to centrifugation, and the clarified broth was extracted with ethyl acetate $1: 1(\mathrm{v} / \mathrm{v})$. The extract was concentrated to give a broth extract $(382 \mathrm{mg})$. It was subjected to reversed-phase vacuum chromatography by a filter funnel on Polygoprep 100-50 $\mu \mathrm{m} \mathrm{C18}$, using a $\mathrm{H}_{2} \mathrm{O}-\mathrm{MeOH}-\mathrm{CH}_{2} \mathrm{Cl}_{2}$ mixture as the eluting solvent. The cytotoxic activity was detected in fractions eluted with $\mathrm{H}_{2} \mathrm{O}: \mathrm{MeOH} 3: 1(35 \mathrm{mg}), 1: 1(100 \mathrm{mg})$ and $1: 3(50 \mathrm{mg})$. As these three fractions displayed similar HPLC profiles, they were combined and evaporated under reduced pressure, resulting in a crude extract $(185 \mathrm{mg})$. This extract was then chromatographed on a reversed-phase $(\mathrm{C}-18)$ column eluted in a stepwise gradient with increasing ratios of $\mathrm{MeOH}$ in water, followed by $\mathrm{CH}_{2} \mathrm{Cl}_{2}$ in $\mathrm{MeOH}$. Three out of the fourteen fractions eluted with $\mathrm{H}_{2} \mathrm{O}-\mathrm{MeOH}$ mixtures showed antitumor activity and similar HPLC profiles. Further purification of two of these active fractions by preparative HPLC was carried out at room temperature using a C-18 Atlantis column $(19 \times 150 \mathrm{~mm}$, $5 \mu \mathrm{m}$, Waters). A gradient of $\mathrm{CH}_{3} \mathrm{CN} / \mathrm{H}_{2} \mathrm{O}(15-60 \%$ in $20 \mathrm{~min})$ was

1PharmaMar S.A.Unipersonal. Avda. Los Reyes, 1. Colmenar, Madrid, Spain and 2 Instituto de Química Médica, CSIC, Juan de la Cierva, Madrid, Spain Correspondence: Dr F de la Calle, PharmaMar S.A.Unipersonal. Avda. Los Reyes, 1. Colmenar, Madrid 28770, Spain. E-mail: fdelacalle@pharmamar.com

Received 8 August 2008; accepted 18 December 2008; published online 23 January 2009 


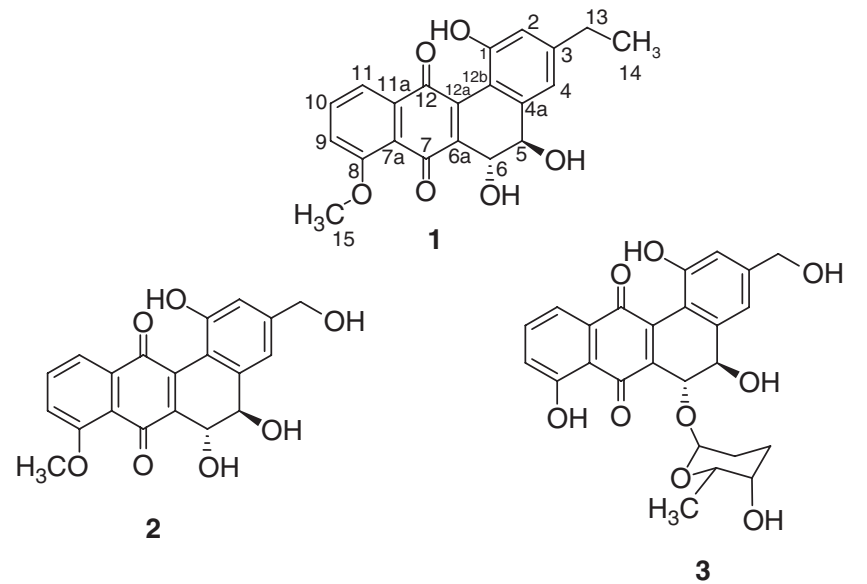

Figure 1 Structures of PM070747 (1), PD 116740 (2) and TAN-1085 (3).

employed as a mobile phase, with a flow rate of $13.65 \mathrm{ml} \mathrm{min}^{-1}$ with UV detection at $215 \mathrm{~nm}$. Under these conditions, a total amount of $5 \mathrm{mg}$ of pure $\mathbf{1}$ was isolated, along with traces of $2 .{ }^{1}$

The structure of 1 was established as shown in Figure 1 on the basis of analysis of the physico-chemical properties (Table 1) and NMR data (Table 2), and by comparison with data reported for the related angucyclinone $2 .{ }^{1}$

The physico-chemical properties of $\mathbf{1}$ are summarized in Table 1 . Compound $\mathbf{1}$ was obtained as a reddish powder. Its molecular formula was determined as $\mathrm{C}_{21} \mathrm{H}_{18} \mathrm{O}_{6}$, on the basis of high resolution electrospray ionization mass spectrum (HR-ESI-MS) and the NMR data (Table 2), indicating 13 degrees of unsaturation.

The ESI-MS experiments showed ions at $\mathrm{m} / \mathrm{z} 367(\mathrm{M}+\mathrm{H})$ and 389 $(\mathrm{M}+\mathrm{Na})$, which confirmed the molecular mass. The UV spectrum of $\mathbf{1}$ in $\mathrm{MeOH}$ exhibited absorption maxima at 203 and $408 \mathrm{~nm}$, indicating the presence of a substituted anthraquinone moiety. The IR indicated the presence of hydroxyl groups $\left(3353 \mathrm{~cm}^{-1}\right)$. In addition, a strong absorption peak at $1639 \mathrm{~cm}^{-1}$ and the absence of a peak near $1670 \mathrm{~cm}^{-1}$ indicated that both carbonyls were involved in hydrogen bonding to neighbouring hydroxyls. ${ }^{78}$ As described for 2 , the absence of an IR band at around $1700-1725 \mathrm{~cm}^{-1}$, assigned to the C-1 carbonyl in related antibiotics, suggested the presence of a hydroxyl group, hydrogen bonded to the C-12 quinone carbonyl, attached to the C-1 position (see Table 1).

The ${ }^{1} \mathrm{H}$ NMR spectrum of 1 exhibited a signal at $\delta 4.00$ for an aromatic methoxy group (Table 2). Moreover, a pair of coupled signals at $\delta 4.59(\mathrm{H}-5)$ and $5.12(\mathrm{H}-6)$ revealed the presence of a 5,6-diol moiety in 1 . Two more signals were observed as doublets with a small coupling constant at $\delta 6.76(\mathrm{H}-2)$ and $6.86(\mathrm{H}-4)$, each integrating for one proton, representing meta-coupled aromatic protons. In addition, an aromatic ABX system with a pattern very similar to that observed for $2^{1}$ was present in the ${ }^{1} \mathrm{H}$ NMR spectrum of $\mathbf{1}$. However, no signals for a benzylic hydroxymethyl group were observed compared with 2 . Instead, coupled signals at $\delta 1.26\left(\mathrm{H}_{3}-14\right)$ and $2.64\left(\mathrm{H}_{2}-13\right)$ clearly indicated the presence of an ethyl group attached to the $\mathrm{C}-3$ position. Assignment of the rest of the benz $[\alpha]$ anthraquinone signals was confirmed by 2-D NMR experiments. In the ${ }^{1} \mathrm{H}-{ }^{1} \mathrm{H}$ COSY, correlations of $\mathrm{H}-10$ with $\mathrm{H}-9$ and $\mathrm{H}-11, \mathrm{H}-5$ with $\mathrm{H}-6$ and $\mathrm{H}-13$ with $\mathrm{H}-14$ revealed the linkages in these substructures. A correlation between the $\mathrm{H}-5$ and $\mathrm{H}-6$ protons in the COSY, together with the observed coupling constant for both protons $(3 \mathrm{~Hz})$, suggested the same trans stereochemistry as that of PD 116740 , the X-ray diffraction analysis of

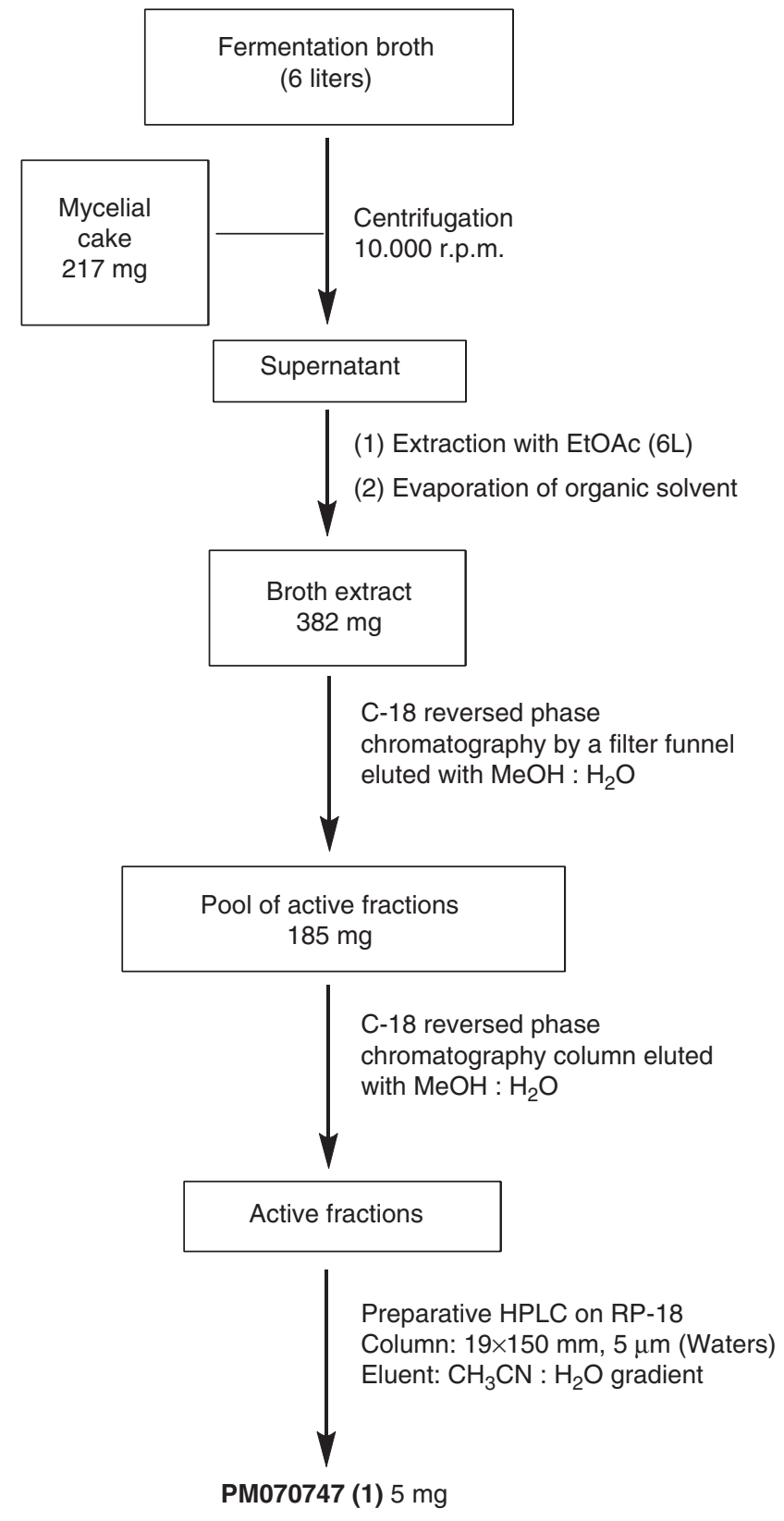

Figure 2 Isolation procedure for PM070747 (1) from the culture of Saccharopolyspora taberi PEM-06-F23-019B.

which has been described in the literature. ${ }^{1}$ The rest of the correlations observed in the ROESY (that is, $\mathrm{H}-4$ with $\mathrm{H}-5$ and $\mathrm{H}-13$; $\mathrm{H}-2$ with $\mathrm{H}-$ 13; H-9 with H-15) were consistent with the proposed structure (Figure 3). The relationship between these fragments was established through the heteronuclear multibond correlation (HMBC) NMR spectrum. The $\mathrm{H}_{3}-15$ methoxy group at $\delta 4.00$ was coupled to the aromatic carbon $\mathrm{C}-8$, indicating its position. Moreover, long-range couplings observed between $\mathrm{H}-13$ with $\mathrm{C}-2$ and $\mathrm{C}-4$ showed the position of the ethyl group (Figure 3). Long-range couplings observed between $\mathrm{H}-4$ with $\mathrm{C}-2, \mathrm{C}-12 \mathrm{~b}$ and $\mathrm{C}-5$, and between $\mathrm{H}-6$ with C-4a, $\mathrm{C}-12 \mathrm{a}$ and the carbonyl group $\mathrm{C}-7$ indicated two substructures fused through C-6-C-6a and C-12a-C-12b, which was further supported by cross peaks between $\mathrm{H}-5$ with $\mathrm{C}-6 \mathrm{a}$ and between $\mathrm{H}-2$ with $\mathrm{C}-12 \mathrm{~b}$ in HMBC as complementary evidence (Figure 3). On the other hand, 
Table 1 Physico-chemical properties of PM070747 (1)

\begin{tabular}{ll}
\hline Appearance & Reddish powder \\
Molecular formula & $\mathrm{C}_{21} \mathrm{H}_{18} \mathrm{O}_{6}$ \\
Molecular weight & 366.364 \\
HR-ESI-MS (pos) $\mathrm{m} / \mathrm{z}$ & $(\mathrm{M}+\mathrm{Na})^{+}$ \\
Calculated & 389.0995 \\
Found & 389.0988 \\
UV $\lambda_{\max }(\mathrm{MeOH}) \mathrm{nm}$ & 203,408 \\
IR $v_{\max }(\mathrm{neat}) \mathrm{cm}^{-1}$ & $3353,2959,1730,1639,1376$, \\
& $1340,860,839,801,738,663$ \\
$(\alpha)_{D}^{25}(c=0.32, \mathrm{MeOH})$ & +220 \\
\hline
\end{tabular}

Table $2{ }^{1} \mathrm{H}$ and ${ }^{13} \mathrm{C}$ NMR (MeOD, 500 and $125 \mathrm{MHz}$ ) assignments of PM070747 (1)

\begin{tabular}{|c|c|c|c|}
\hline Position $\mathrm{C} / \mathrm{H}$ No. & ${ }^{1} H$ shifts ${ }^{\mathrm{a}, \mathrm{b}, \mathrm{c}}$ & ${ }^{13} \mathrm{C}_{\text {shifts }}{ }^{\mathrm{a}}$ & $H M B C$ \\
\hline 1 & - & 157.34 & - \\
\hline 2 & $6.76 \mathrm{~d}, 1 \mathrm{H}(J=2)$ & 118.53 & $C-1, C-13, C-12 b$ \\
\hline 3 & - & 150.40 & - \\
\hline 4 & $6.86 \mathrm{~d}, 1 \mathrm{H}(\mathrm{J}=2)$ & 123.21 & $C-2, C-5, C-12 b, C-13$ \\
\hline $4 a$ & - & 143.04 & \\
\hline 5 & $4.59 \mathrm{~d}, 1 \mathrm{H}(J=3)$ & 72.79 & $C-4, C-12 b, C-6 a$ \\
\hline 6 & $5.12 \mathrm{~d}, 1 \mathrm{H}(\mathrm{J}=3)$ & 64.69 & C-7, C-4a, C-12a \\
\hline $6 a$ & - & 141.88 & \\
\hline 7 & - & 184.32 & - \\
\hline $7 a$ & - & 120.80 & \\
\hline 8 & - & 160.70 & - \\
\hline 9 & $7.50 \mathrm{~d}, 1 \mathrm{H}(J=8)$ & 119.14 & C-11 \\
\hline 10 & $7.77 \mathrm{dd}, 1 \mathrm{H}(J=7.5,8)$ & 136.22 & C-8, C-11a \\
\hline 11 & $7.69 \mathrm{~d}, 1 \mathrm{H}(J=7.5)$ & 120.18 & C-9, C-7a \\
\hline $11 \mathrm{a}$ & - & 137.58 & \\
\hline 12 & - & 187.49 & \\
\hline $12 a$ & - & 140.27 & \\
\hline $12 b$ & - & 114.42 & \\
\hline 13 & $2.64 \mathrm{q}, 2 \mathrm{H}(J=7.5)$ & 29.66 & $\mathrm{C}-2, \mathrm{C}-3, \mathrm{C}-4$ \\
\hline 14-Me & $1.26 \mathrm{t}, 3 \mathrm{H}(J=7.5)$ & 15.56 & C-3 \\
\hline 15-Me & $4.00 \mathrm{~s}, 3 \mathrm{H}$ & 56.83 & $\mathrm{C}-8$ \\
\hline
\end{tabular}

aChemical shifts $(\delta)$ are in ppm.

${ }^{b}$ Coupling constants $(\mathrm{J})$ in hertz $(\mathrm{Hz})$ are given in parentheses.

cs: singlet; d: doublet; t: triplet; q: quartet.

C-7a was assigned by its correlation with $\mathrm{H}-11$, and the $\mathrm{C}-11$ a position was revealed by a cross peak between $\mathrm{H}-10$ and $\mathrm{C}-11 \mathrm{a}$ in $\mathrm{HMBC}$ (Figure 3).

The antitumor activity of $\mathbf{1}$ was evaluated against a panel of three tumor cell lines: human breast adenocarcinoma MDA-MB-231 cells, human colorectal adenocarcinoma HT-29 cells and human lung carcinoma A-549 cells (concentration of 50\% inhibition on cell growth $\left(\mathrm{GI}_{50}\right) 0.71,1.42$ and $3.28 \mu \mathrm{M}$, respectively), according to the procedure described in the literature. ${ }^{9}$ Cell survival was estimated using the National Cancer Institute algorithm. ${ }^{10}$ Three dose-response parameters were calculated for $\mathbf{1}$ (Table 3 ).
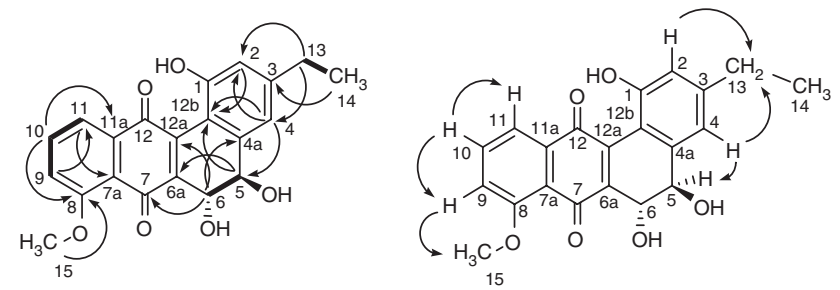

$\longrightarrow{ }^{1} \mathrm{H}-{ }^{1} \mathrm{H} \cos Y$

Figure 3 Summary of $1 \mathrm{H}-1 \mathrm{H}$ COSY, HMBC and ROESY correlations in PM070747 (1).

Table 3 Cell-survival values $(\mu \mathrm{m})$ for three tumor cell lines treated with PM070747 (1)

\begin{tabular}{lccc}
\hline & A549 & HT29 & MDA-MB-231 \\
\hline $\mathrm{Gl}_{50}$ & 3.28 & 1.42 & 0.71 \\
$\mathrm{TGI}$ & 4.64 & 1.97 & 1.06 \\
$\mathrm{LC}_{50}$ & 6.82 & $>2.73$ & 1.72 \\
\hline
\end{tabular}

$\mathrm{Gl}_{50}$, compound concentration that produces $50 \%$ inhibition on cell growth as compared with control cells; TGI, compound concentration that produces total growth inhibition as compared with control cells; and $\mathrm{LC}_{50}$, compound concentration that produces $50 \%$ cell death as compared with control cells.

\section{ACKNOWLEDGEMENTS}

We gratefully acknowledge the assistance of our PharmaMar colleagues, Dr Luis Francisco Garcia for the cytotoxicity assay, Dr Susana González for performing the NMR experiments, Jesus Garcia for the microbial cultures, and Dr Simon Munt and Dr Fernando Reyes for the revision of this paper.

1 Wilton, J. H., Cheney, D. C., Hokanson, G. C., French, J. C., Cunheng, H. \& Clardy, J. A new dihydrobenz[a]anthraquinone antitumor antibiotic (PD 116740). J. Org. Chem. 50, 3936-3938 (1985).

2 Kanamaru, T., Nozaki, Y. \& Muroi, M. TAN-1085 and its aglycon as angiogenesis and aromatase inhibitors and their manufacture with Streptomyces species Japanese patent 02289532 (1990). Takeda Chemical Industries, Ltd, Japan.

3 Li, X., Yao, Y., Sun, G., Zheng, Y., Lin, W. \& Scattler, I. Studies on chemical structure of an anthraquinone derivative from marine fungus Penicillium. Fenxi Ceshi Xuebao 26, 195-197 (2007) (in Chinese).

4 Atlas, R. M. (ed). In Handbook of Microbiological Media 3rd edn, 205-206 (CRC Press LLC, NW Corporate Blvd, Boca Raton, Florida, 2004).

5 Altschul, S. F. et al. Gapped BLAST and PSIBLAST: a new generation of protein database search programs. Nucl. Acids Res. 25, 3389-3402 (1997).

6 Labeda, D. P. Transfer of the type strain of Streptomyces erythraeus (Waksman 1923) Waksman and Henrici 1948 to the genus Saccharopolyspora Lacey and Goodfellow 1975 as Saccharopolyspora erythraea sp. nov., and designation of a neotype strain for Streptomyces erythraeus. Int. J. Syst. Bacteriol. 37, 19-22 (1987).

7 Sun, C. H. et al. Chemomicin A, a new angucyclinone antibiotic produced by Nocardia mediterranei subsp. kanglensis 1747-64. J. Antibiot. 60, 211-215 (2007).

8 Bloom, H., Briggs, L. H. \& Cleverley, B. Physical properties of anthroquinone and its derivatives. Part I. Infrared Spectra. J. Chem. Soc. 178-185 (1959).

9 Skehan, P. et al. New colorimetric cytotoxic assay for anticancer-drug screening. J. Nat Cancer Inst. 82, 1107-1112 (1990).

10 Robert, H. S. The NCI60 human tumour cell line anticancer drug screen. Nat. Rev. Cancer 6, 813-823 (2006). 